\title{
内分泌攪乱化学物質がもたらす社会的インパクトの解析
}

\author{
社団法人環境情報科学センター 勝 田悟 \\ 株式会社第一勧銀総合研究所阪 口 直 樹
}

\section{Social Impact of Endocrine Disrupting Chemicals}

\section{Satoru Katsuda}

Center for Environmental Information Science

\section{Naoki Sakaguchi}

Project Research Dept,

Dai-ichi kangyo research Institute

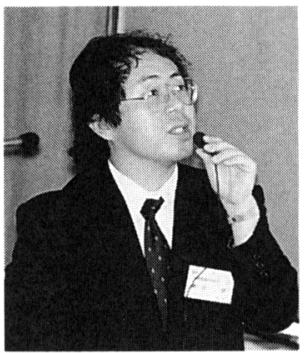

勝田＼cjkstart悟

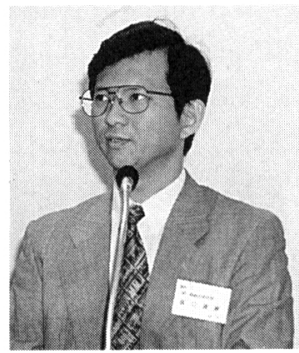

阪口直樹

Chemical substances are the underpinnings of science, technology and life. Some of the most important of science and technological development were associated with material's character. Materials of all kinds are becoming more sophisticated. Endocrine disrupting chemicals was included these many materials in our life.

We do not know about a right characteristic of these endocrine disrupting chemicals. But we expect that will generate social impact. The analysis of social impact must be human dimension research. Particularly, I think that the company have to implement the following:

(1) Environmental information (material safety data sheet, several monitoring)

(2) Education about products :

(3) Product liability

(4) Risk potential

(5) Marketing

(6) Environmental performance

分類 : $X_{1}$ 環境総論, $Z_{1}$ 産業・経営総論

\section{1. 環境問題全般における環境ホルモン污染}

近年の環境污染は，時間的空間的な広がりを示して いる。地域環境污染, 地球環境污染, 及び食品污染な ど様々な経路で污染が拡大している。また, 人間活動 の広がりや人口の増加などを背景に污染と原因の関係 の複雑化が漸次進んでいる。内分泌摚乱化学物質污染 (以下環境ホルモン污染とする)は, 人間に直接的に影 響を示すものである。しかし，その機序はまだ解明す べき点が多く, 現在のところ原因物質と被害の因果関 係は高い蓋然性をもって証明することは不可能である。
全般的な環境問題の中でも，特に環境ホルモン污染 は生物の生殖機能や経世代への被害に係わっており, 人間への影響も懸念されることから，一般公衆に高い 危険意識が広がっている。全般的な環境問題の中での, 環境ホルモン污染の関係を図 1 に示した。

なお，環境問題は，人に対して何らかの損害（物権 及び人格権）を生じるものを取り上げ，動物愛護等は 対象とはしていない。

\section{1 污染の広がり（図 1 の横軸方向の考察）}

化学物質による環境污染は, 物質が環境中に放出さ れることにより，大気，水，食物等（濃縮も含む）各 


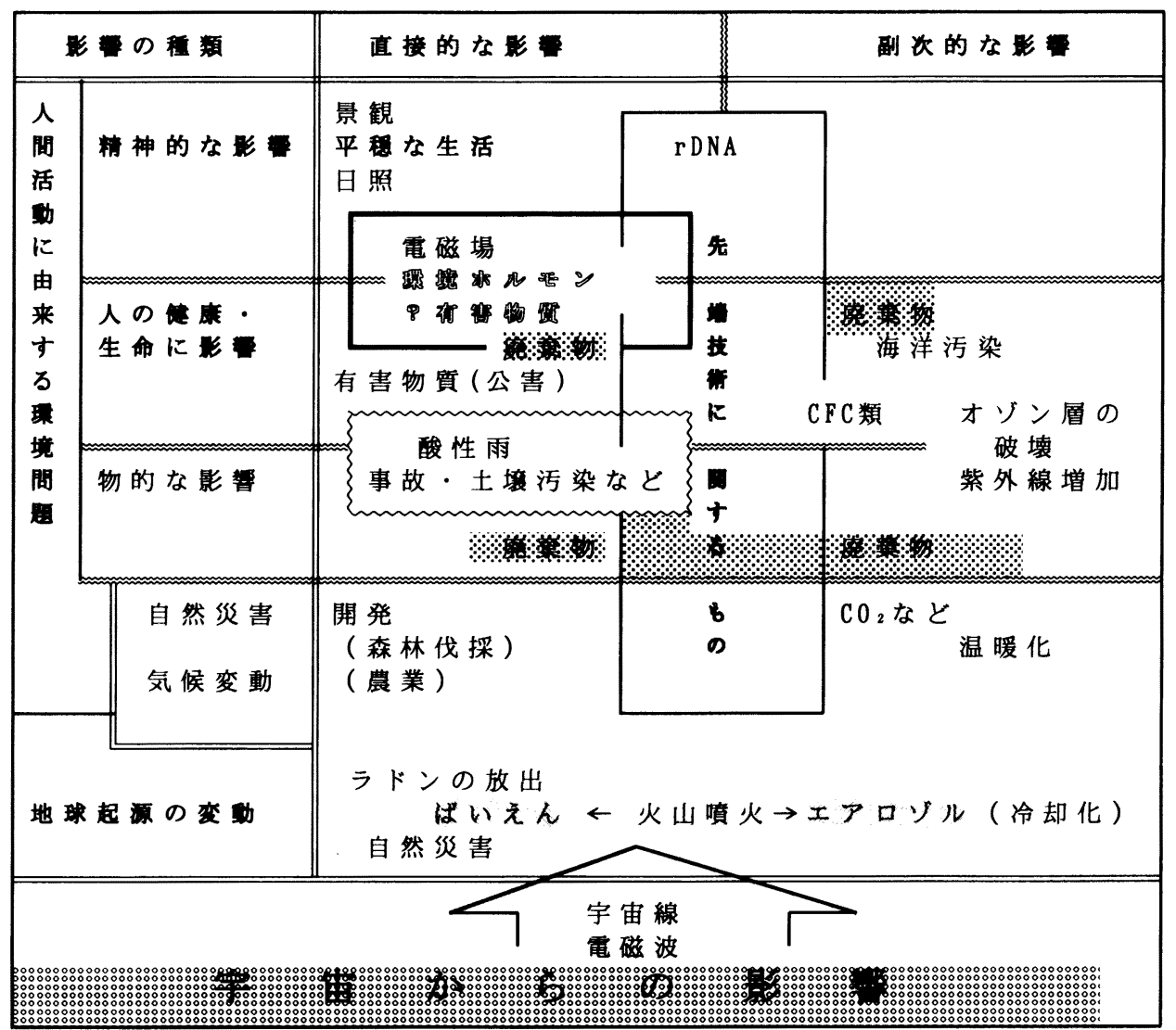

*逗剩なリスクと思われる精神的なものは除外した

図 1 環境問題全般における環境ホルモンの位置

種媒体に拡散していく。これら污染物質は，生命，健 康が直接侵害されるようなものから，化学物質が環境 中で何らかの化学反応を生じ，反応物が人間に影響す るものもある。一方, $\mathrm{CFC}$ 類（商品名：フロン）は, 洗浄剤や冷媒等として非常に安全で (安定で) 高性能 な物質であるが，成層圈での反応によって地球大気環 境の物質バランスを破壊し，紫外線による人の健康侵 害を起こしている。温暖化においては，主要原因物質 で環境中で非常に安定である二酸化炭素が，大気中で の存在比を増加させたことにより気象変化を発生させ ている。

副次的な影響が生じるほど，その原因と被害の科学 的な解析が指数的に複雑となり，被害の補償は困難と なる。また，被害地域が広がると，損害の有無や污染 被害と污染者の利益等，政治的な判断を含んだ国家的 または国際間の比較衡量が必要となる。

環境ホルモン污染は, 経口捸取や皮虑等の吸収に よって，直接人間を污染（人格権侵害）する。物質の
直接的環境放出や人間活動によって生じた化学反応に よって生成した物質の放出によって人体捸取されるこ とが現在問題となっている。具体的には，工場等から の排出物，製品からの溶出等，食品への混入や各種製 品の焼却による反応物生成などが挙げられる。環境ホ ルモンは人間の健康，生命に影響するもので，気象異 常など地球環境に影響するような副次的な環境污染物 質ではない。発ガン性の問題で注目されたダイオキシ ンが環境ホルモン物質の疑いがあることから，ダイオ キシンの発生過程, 排出経路が代表的な環境ホルモン 污染例といえる。

環境ホルモンの可能性がある化学物質の環境中また は市場での移動経路をすべて調査するには，極めて多 くの種類の物質を対象とした膨大な作業量が予想され る。これらを合理的に行うには，社会全般を対象とし た総合的な化学物質管理が不可欠であろう。しかし, 現在国際的に進められている化学物質移動登録 (PRTR) 制度でさえ，国際的な歩調はとれていない。 
現状では，化学物質による潜在的な環境りスクを減ら すための何らかの政策的な対策に期待するしかないで あろう。

\section{2 污染の種類（図 1 の縦軸方向の考察）}

環境污染の種類には，人間活動に由来した様々なも のがある。また，地球を起源とした環境変動や宇宙か らの影響もあり，それぞれが複雑に関係しあっている。

（1）精神的な影響

人の社会的な権利として 1970 年以来「環境権」が取 り上げられており, 平穞な生活の一つとして環境保全 が行われている。環境権は，そもそも憲法 13 条の「国 民の幸福を追求する権利」, 及び憲法 25 条の生存権と して定められた「国民は健康で文化的な最低限度の生 活を営む権利」に基づいた基本的権利として提唱され たものである。公害問題から日照権などまで, 環境問 題が拡大される重要な根拠と言える。しかし, 新技術 の未知のリスクに対して污染未然防止を目的として争 われた「遺伝子組換え体実験 (P 4 施設差し止訴訟) 中止」は，裁判ではその危険性は認められていない。 その理由は, 明らかに示される技術の有益性の価值と, 科学的な根拠が明確でなく抽象的な確率でしか判断で きない潜在的なリスクの比較において衡量されたため と思われる。結果的には，これらは人の精神的な影響 として取り扱われることになる。よって，人の感覚的 な判断による「景観に関わる環境問題」と近似してく るところも大きい。環境ホルモンも，科学的な根拠に 基づく安全性は, リスクの 0 ではない確率の数値が問 題となることが多い。空間的時間的な広がりに基づく 多変量の解析で求めるリスクの確率が, 危険または安 全と判断するかは, 多くの環境りスク問題の共通課題 である。最近では, 欧米を中心に疫学調査が盛んに行 われている「電磁場の生体影響」が類似している環境 問題と言える。

\section{（2）人の健康・生命に影響}

人の健康・生命に影響するものとしては, 有害性を もった化学物質によるものが中心である。地球上に 10 万物質以上の化学物質が存在し, 約 1,500 物質が各種 産業に頻繁に使用されている。また，米国化学会登録 の化学物質は 1,700 万物質以上あり, 自然界に存在し ない物質を人類は膨大に作りだしている。それら物質 の多くは，産業用の性質しか確認されておらず，慢性 毒性等有害性が不明なものの方が圧倒的に多い。内分 泌を摚乱する性質をもつ物質も膨大に存在することも 予想される。さらに, 酸による溶出や柴外線による分 解など環境中で発生する反応を考慮すると, 科学的な 有害性の解明は極めて困難である。
有機水銀, カドミウム, 及びヒ素による污染の原因 でさえ, 未だに科学的な検討が行われているのが現状 である。まして, さらに複雑な化学的構造をもつ物質 の環境中や生体内での挙動を把握することは, 困難を 極める。

また，油濁事故などで油の分散剤として使用される 界面活性剤には, 環境ホルモンの疑いがあるノニル フェノールも利用されている。分散剤は, 污染油を海 水 (または淡水) で希釈拡散 (例. 台所の洗剤)するた めに散布され, 最終的には土着の微生物によって捸取 される。有害物質の生物濃縮は当然発生することも予 測できる。しかし，污染海域（または地域）をそのま ま放置することは, 漁業や観光産業への損害が大きい ため, 污染海域のプランクトンの慨となる処理の促進 が優先される。守るべき「環境の価値」の基本的な概 念が問題となる。環境の循環システム内に人工的な化 学物質が混入してくると, 環境の物質バランスが不安 定となり, 被害の回避には人の価值判断の比較が最も 重要となってくると言える。廃萧物処理や LCA の検 討でも同様な問題が発生しており，人間活動のあらゆ る部分で今後の課題となってくると思われる。環境ホ ルモンは生活の利便性を追求したことによって普及し た材料に含まれていることが多く，人の利益とリスク の比較衡量が重要な視点となりうる。但し, リスクの 正しい理解が十分になされていないと,リスクの指数 的勘違いが発生することに中止しなければならない。 例之ば，缶ジュースに微量含まれる物質やプラスチッ ク製食器に含まれる超微量物質などのリスクの大きさ の冷静な判断が必要であろう。

(3) 物的な影響

コンクリートで作られた建造物は, 鉄骨の酸化防止 のために塩基性の材料となっているが, 酸性雨の影響 により酸性つららなど腐食が発生している。悪化する と劣化が進み崩落等が発生する。また, わが国の樹木 は欧米に比較して酸に強い種類のものが多いのであま り顕著に現れていないが, 酸性雨による森林の破壊や 土壤の変質が発生している。

有機塩素系化合物等の土壌污染は確実に広がってい る。特にわが国では土地の価値が非常に高いため, 早 期に対策が実施されないと污染土壤の土地価格の急激 な低下が起こることが予想される。抵当権が設定され た土地の担保権が著しく低下することも考えられ, 不 良債権の増加も称念される。土壤改善には, 膨大なコ ストが費やされるため, 土地所有権者や占有権者には 細心の注意が必要だろう。米国のスーパーファンド法 (CERCLA : Comprehensive Environment Res- 
ponse, Compensation and Liability Act 及 び SARA : Superfund Amendments and Reauthorization Act) や RCRA (Resource Conservation and Recovery Act) では, 土壤污染に対して厳しい罰則が 定められており, 損害賠償訴訟では污染者, 所有権者 や貸し手責任者等に嶶罰的な責任が認められている。 わが国では, 民事では懲罰的な責任は認められていな いが, 土地への極めて高い価值意識があるため, 大き な社会問題となりうることが予想される。今年 (1999 年） 7 月 13 日に制定された「特定化学物質の環境への 排出量の把握等及び管理の改善の促進に関する法律」 所謂 PRTR 法は, 污染土壌確認の基礎情報と成りうる 可能性がある。但し, 貯蔵量や売買による移動量は本 法律の対象となっていないため, 具体的な直接情報と は成らない。近年大手企業で二酸化炭素の排出を中心 に行われているライフサイクルアセスメント (LCA) の検討とリンクすれば合理的な対応が期待できるだろ j。

環境ホルモン物質は, 生殖異常や慢性的な悪質な毒 性を有し，マスメディアへの多くの報道等によって一 般公衆へ衝撃的に感心を高名いる。污染土壤に対し て潜在的リスクが最も高く評価されると思われる。環 境中に多量に散布される農薬, 地下水污染が問題と なった有機塩素系化合物や環境中で一般に使用されて
いた有機錫化合物や PCB は, 特定の土壌に蓄積され ている可能性がある。

現在は使用されていないが, 以前に農薬中に含まれ ていた水銀化合物は, わが国中に多量に散布され，現 在でも一般環境中に微量に存在してしまう結果となっ ている。自然のバランスから冕脱した人工化学物質は, 既に多く存在していることが予想される。ホルモン様 物質は，多くの種類があるため事前に注意すべきもの も膨大になるだろう。

(4) その 他

無計画な都市開発等によって発生した自然災害や温 暖化によって発生した気象異常も環境污染の一種と考 えられる。自然のエネルギーは人の想定を超えた大き さを表すこともあり，大災害をもたらすことがある。 高度な技術が導入された農業や漁業も自然のバランス を変化させている。また, 地球の様々な活動から発生 する化学物質もある。火山の噴火によるエアロゾルの 放出は地球の冷却化を招くこともある。鉱山や地下に 存在するラジウムから数度の壊変によって生成したラ ドンは, 気体の放射性物質となり, 人が吸入した場合 その後改変したポロニウムによって肺に障害を生じる こともある。さらに, 宇宙からは高いエネルギーをもつ ている宇宙線も地球に降り注いでいる。地球の磁場が バリヤとなり宇宙線からの影響を防止しているが,

表 1 地球上での化学物質の拡散

\begin{tabular}{|c|c|c|c|}
\hline & 変 & 拡散される物質 & 一般環境への負荷 \\
\hline 工業 & 技術の進展 & $\begin{array}{rr}\text { 多種類の物質の使用 } & \text { 研究 } \\
& \text { 生産 } \\
& \text { 多種類の物質を含んだ製品 }\end{array}$ & $\begin{array}{l}\text { 放出・廃棄 } \\
\text { 放出・廃棄 } \\
\text { 放出・廃㫣 }\end{array}$ \\
\hline 農業 & $\begin{array}{c}\text { 生産量の拡大 } \\
\text { 農地拡大 } \\
\text { 効率的生産 }\end{array}$ & 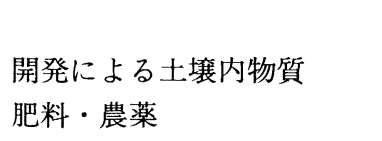 & $\begin{array}{l}\text { 放出 } \\
\text { 放出 }\end{array}$ \\
\hline 生活 & 生活様式変化 & $\begin{array}{l}\text { 多くの物質が散在 } \\
\text { エネルギー消費 } \\
\text { 建物（防腐剂等） }\end{array}$ & $\begin{array}{l}\text { 廃棄 } \\
\text { 放出 } \\
\text { 放出 }\end{array}$ \\
\hline エネルギー & $\begin{array}{l}\text { 新エネルギ一開発 } \\
\text { エネルギーの確保 }\end{array}$ & $\begin{array}{l}\text { (原子力推進) 放射性廃棄物 } \\
\text { 太陽電池 : 含有半導体等 } \\
\text { 再生電池 : } \mathrm{Ni}-\mathrm{Cd}, \mathrm{Li} / \mathrm{Co}\end{array}$ & $\begin{array}{l}\text { 廃棄 } \\
\text { 廃棄 } \\
\text { 廃棄 }\end{array}$ \\
\hline 廃棄物処理 & $\begin{array}{l}\text { 燃焼 } \\
\text { その他 }\end{array}$ & 燃焼生成物 & $\begin{array}{l}\text { 放出 } \\
\text { 残査 } \\
\text { 残查 }\end{array}$ \\
\hline
\end{tabular}

*放出は，「意図的なもの」または「非意困的なもの」 
1500 年から 2000 年後に地球の磁場の反転が起こった ときは生物生存の維持は不可能となるだろう。また, 人類が打ち上げた人工衛星の破片（スペースデブリ） が, 地球の周りに飛び散ったまま低軌道を回転してい る(5871 個, 1822 トン)。原子力電池搭載衛星がスペー スデブリと衝突して落下した場合大きな災害となる可 能性がある。

このように現在環境污染は様々なものがあり，その 中の一つとして環境ホルモン問題があることを理解す る必要がある。環境ホルモン物質は, 污染被害の新し い機序をもつため社会的なインパクトが大きくなって いる。しかし, 本問題に具体的に対応するには, 他の 污染問題を考慮し広い視野で検討していくことが重要 である。

\section{2. 環境ホルモン等有害物質の拡散}

\section{1 有害物質の拡散}

技術の進展, 人口の増加, 生活椂式の変化によって, 人工的に作られた化学物質は, 地球上で漸次拡散して
いっている。即ち, 人間活動の拡大が環境污染の拡大 となっている。環境ホルモン物質も同様に人間活動の 活動に従って, 地球上で拡散していっている。農薬に は, 環境ホルモンとして疑わしい物質が多く, 今後の 検討が待たれる(表 1$)$ 。

\section{2 拡散した物質の検出}

化学分析技術の進展により, 超微量物質の定性・定 量が可能となり，環境ホルモン物質も確認できるよう になった。ダイオキシンの分析などかなり高い精度が 要求されるものも可能となっている。但し, 環境ホル モンの有害性についての実験の再現性では, まだ学会 で議論されている。また，時間的な広がりが大きい慢 性毒性については, 測定も経時的なデー夕が必要とな り信頼性の高い結果を得ることは難しい（図 2)。

定性が明確となれば，物質の MSDS (Material Safety Data Sheet) 情報が事前対策として重要とな る。本情報に基づいて, 測定計画やリスク分析, リス ク対応が検討されることとなる。モニターされる物質 は, 物質の環境中での挙動を考虑して, 環境計量が行

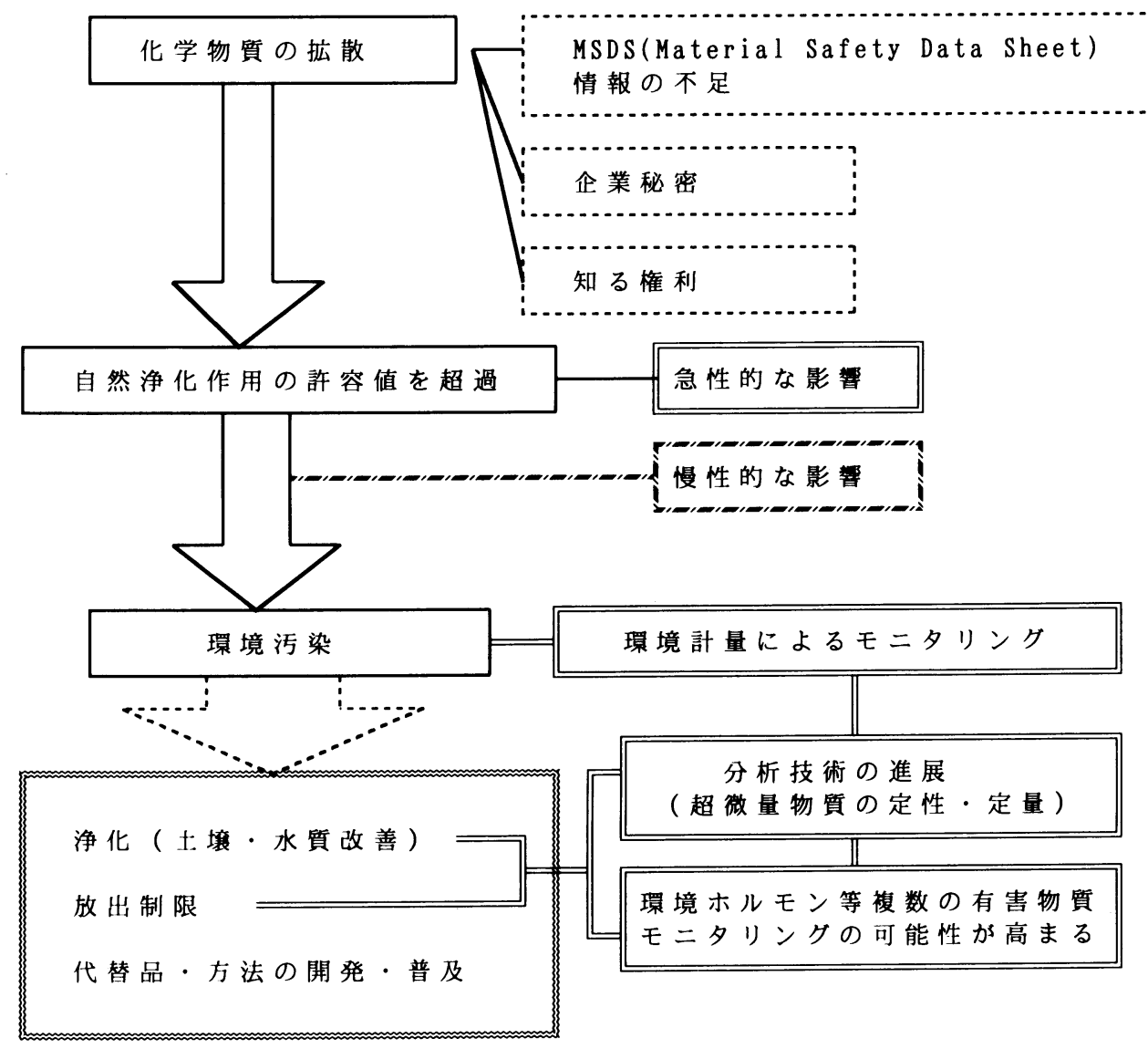

図 2 化学物質モニター 
われる。わが国では，環境計量は環境計量法に基づい て行われる。比較的システマチックに行われる物質の 計量によるモニターは, 現在はほとんどが, 環境保全 に関連した行政法の規定に従っている。これらは，污 染の再発防止を目的として行われている。今後は, 土 䁃污染など事後処理のための污染物質の検知も普及し ていくと思われる。一方, 大気污染防止法の 18 条 21 の 事業者の責務や PRTR 法で, 物質排出者側の化学物質 の管理面での向上も期待でき, 各種環境情報に基づい た企業環境パフォーマンスの評価の検討の進展も望ま れる。

\section{3. 環境ホルモンの有害性}

\section{1 物質の有害性の種類}

\section{(1) 複合的な影響}

環境ホルモン物質は, 既存の急性的毒性や各種慢性 的毒性を示すものが多く，既に環境法等で使用制限や 環境計量の義務づけがあるものが多い。このような情 報は，前述の MSDS で確認することが出来る。

内分泌挸乱以外の物質の有害性の種類の例を次に示 す。

(1)急性毒性/中毒等 (ヒ素 [化合物], シアン化合物 $[\mathrm{K}, \mathrm{Na}])$

(2)慢性毒性／発ガン性など（ダイオキシン，トリク ロロエチレンなど)

(3)物理的影響（アスベスト，電磁場)

(4)その他（新たな性質による污染）

化学物質は，環境中で空気酸化や紫外線による高工 ネルギーの吸収などで化学反応し有害性を示す場合が ある。例えば, 六価クロムは, 次亜塩素酸ナトリウム 等で還元処理（公害処理）し，三価クロム（有害性が $1 / 100$ となる)が, 環境中で酸化され六価クロムとなる ことがある $\left(\mathrm{Cr}^{+3} \rightarrow \mathrm{Cr}^{+6}\right)$ 。

人の生命・健康を侵害するような化学物質の性質 (新 しい污染）は，今後も発見または予見されることがあ り, MSDS の項目やデータは常に更新していく必要が ある。一つの物質でも複数の種類の有害性を有し, さ らに通常の污染被害には, 複数の種類の物質が関わっ ていることが多いため，被害 (損害) と原因の因果関 係を証明することは非常に困難である。個々の物質に よる污染被害の発現する時期が異なる場合, 様々な情 報の解析が必要となり原因の特定は困難さを深める。 また, 被害の発現までに長期間を要することにより， その他の複合要因が指数的に増加し污染被害自体不明 瞭となる。

(2) 環境ホルモンの性質の例
環境ホルモンの性質について，市民及び企業にヒア リング調査を行った際の共通の認識を次に示す。

(1)内分泌攪乱化学物質とされるものは, 様々な産業 分野, 生活全般で使用されており, 極めて広い分野へ の影響が予想される。

(2)被害と原因の科学的な因果関係が不明確である。

対象となる物質が非常に多いことが, 污染の可能性 がある範囲を大きくしている。当該物質を含む製品を 製造・販売・流通する企業は, 規模を問わず関わって おり, 関連情報の入手や尃門的知識を必要とする対応 が困難な場合がある。

次に代表的な環境ホルモン物質の MSDS データを 記載する (表 2)。

\section{2 環境ホルモンの有害性の証明}

(1) 被害と原因

環境ホルモン污染の証明には科学的に高度な解析が 必要とされるため表 3 の項目の検討が重要である。

環境中の多くの物質が環境ホルモンの可能性があり, 污染の経路, 原因の特定が難しく, 污染と原因の関連 の蓋然性も低い。よって, 被害と原因の因果関係を証 明することは難しい。過去の公害のように, 蓋然性を もって, 污染被害の責任を問うことは極めて困難であ る。また, ゴミ処理やリサイクルのように受益者負担 によって，対策を講ずることも現状では難しい。

(2) 污染の確定の考え方

環境ホルモンは, 生体内での有害性の機序がまだ科 学的に十分に解明されていない。IPCC (Intergovemmental Panel on Climate Change) での温暖化の環境 影響の確定の議論を参考に, 環境ホルモンの污染の確 定を考えてみたい。

IPCCにおける影響の証明とコンセンサスの水準の 関係を図 3 に示す。

1) 污染の科学的な証明の度合が低く利害関係者の合 意レベルの低い場合 (Speculative) は，まだ検討の必 要がある部分として扱われる。2)証明の度合が高く合 意レベルが低い場合（Well-Posed Controversy）は, 合意を得るための困難な論争の部分とされる。3)証明 度が低く合意レベルが高い場合 (Probable) は, 污染 の蓋然性がある部分として取り扱われる。4) 証明度が 高く合意レベルが高い場合 (Well-Established) は, 污染が確定した部分として扱われる。

4）（Well-Established）となれば，法律によって強 制力がある環境污染対策が実行できる。具体的には, 物質の性質に応じた排出抑制または使用制限等が科学 的根拠に基づいて行われ, 悪質な行為の防止には罰則 による取締りも可能となる。しかし，その他の場合， 
表 2 環境ホルモン物質のセーフティデータシート

(その 1)

ノニルフェノールＣAS No.25154-52-3

•C $9 \mathrm{H} 19$ •C $6 \mathrm{H} 40 \mathrm{H}$ の構造で無色または淡黄色の液体で, 商品には, 少量の不順物を含む。微かな石炭 酸臭がある。

- 一次的な用途

／界面活性剂（アニオン活性剂，非イオン界面活性剂）

フェノール樹脂等の中間物の原料, 殺虫剂, 殺菌剤, 防かび剤

／エチルセルロースの安定剤（エチルセルロース（(CAS No.90004-57-3）は，ラッカー，インキワニ

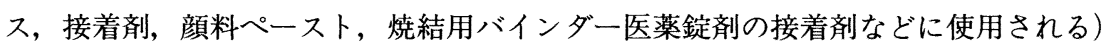

・ 二次的な用途

/洗剤，ゴムの助剂，加硫促進剤，石油系製品の酸化防止剤，腐食防止剂，石油類のスラッジ生成防止剂

・価格 350 円 420 円 $/ \mathrm{kg}$ (年間生産約 2 万トン)

(その 2)

ビスフェノール A CAS No.80-05-7

別名：BPA

・分子式 $\mathrm{C}_{15} \mathrm{H}_{10} \mathrm{O}_{2}$ で, 白色の結晶性粉末フレーク又は粒状の外観 である。

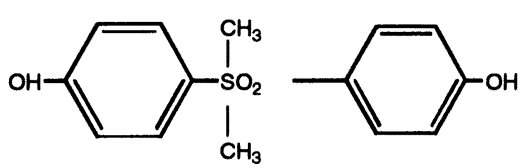

・ポリカーボネート樹脂, 工ポキシ樹脂などの原料が種である。

この他酸化防止剂, 塩化ビニル安定剂などに使用される。

・許容濃度の定めはないが，皮䖉，目を刺激する。

—(その 3$)$

ポリ塩化ビニル CAS No.9002-86-2

別名：塩化ビニル樹脂, PVC, ポリビニルクロライド

・— CH 2-CHC 1$)_{n}$ の構造を持ち, 無色無臭の球形の粉末成形には, 安定剤, 可塑剤など, 補助材料が加之 られる。材質は，JIS 规格によって定められている。

$/ \mathrm{mp}$ (融点) : $170^{\circ} \mathrm{C}, 190^{\circ} \mathrm{C}$ 以上で熱分解し塩化水素を発生する

/耐薬品が高い。

／難燃性材料（ハロゲンを含む）で，塩化パラフィン，酸化アンチモンを添加することによって，さらに

難燃度が高まる。但し燃焼するとダイオキシンを発生する可能性がある。

- 軟質製品

: 日常家庭用品類

/雨具 (傘, 長靴, レインコート・合羽), 鞄

玩具（浮き袋，人形など）

履き物（サンダル，スリッパなど）

室内装飾（壁紙，クッションなど）

紙加工頻（本，ノートの表紙，ファイル類）

食品等各種包装材, 台所製品（ラップ，スポンジ類）

: 工業・農業用品（押し出し成形）

／電線被膜, 配管被覆材, ホース類, 塩ビ鋼板, 農業用各種シート

・硬質製品

／配管類（継ぎ手，上下水道管），耐薬品用配管

・合成緎維（ポリ塩化ビニル繊維）

/毛布, ふとん綿, 肌着, 漁網, ロープ

（*軟質製品は，可塑剂を $25 \%$ ～50\%，硬質製品は，可塑剤を $10 \%$ 以下含む)

・価格 ポリマー156〜161 円 $/ \mathrm{kg}$, コポリマー200〜350円 $/ \mathrm{kg}$ 
・ゴム, 皮革, 木材, 綿, 金属等の代替材料として, 機械的特性, 耐熱性, 電気特性, 化学的特性を向上させ たものが開発され，実用化・普及されつつある。

- (その 4)

ポリカーボネートＣAS No.25971-63-5

・ポリカーボネートは, 一 (O-R-O-CO) n一の形をした高分子化合物である。

/一般的なものとしては, ビスフェノールAのポリ炭酸エステルが上げられる。

- 家庭用品, 自動車用部品, 電気絶縁用材料, 建築用材料

/台所用ボール，ほ乳瓶，おしやぶり等

/光ディスク，ラミネート・コーティング材料等金属を代替する部分に普及されつつある。

・透明な難燃性熱可塑性プラスチック

・価格 $\quad 470 \sim 530$ 円 $/ \mathrm{kg}$ (年間 15 万トン生産)

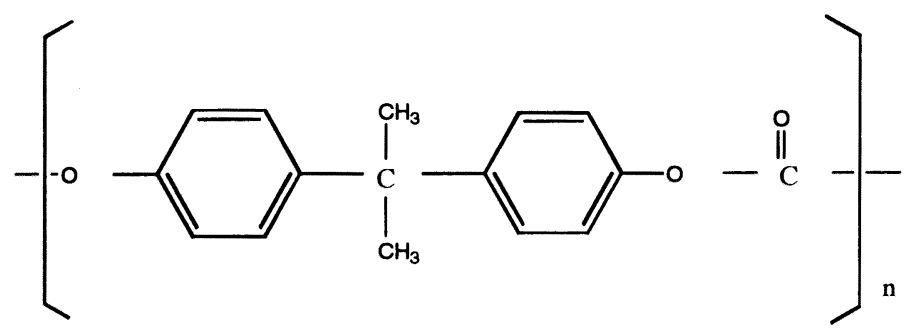

くこの他の代表的な熱可塑性プラスチックス $>$

・ポリ塩化ビニル（年間生産約 200 万トン）

用途：包装材等日常品全般, 電線破履材など

・ポリ眽酸ビニル (年間生産約 55 万トン)

用途：接着剤, 纎維加工剂, チューインガム, ビニロン原料

・ポリスチレン (年間生産約 140 万トン)

用途：テレビ・冷蔵庫・ラジオ等のパネル, 玩具, 建具, 合成紙

ディスポーザブルカップ

・ポリエチレンテレフタレート（年間生産約 125 万トン）

用途：食品容器／醬油，ソース，清涼飲料，食用油など

医薬品・化粧品・医薬品容器, 電子レンジ用容器

電気電子機器 $\cdot$ 自動車部品

・ポリメチルメタクリレート（年間生産約 60 万トン）

用途：雑貨 (傘の柄, 洗面器・風呂いす)

光ファイバー, 光ディスク基盤, 航空機等の風防がラス

表 3 環境ホルモンの有害性の予測と回避

(1)被害の予見可能性があると判断するための要件

臨床試験, 疫学調査 /知見の評価の項目と方法の

検討

調查項目：原因と結果の因果関係及び蓋燃性

考 慮 点: 調查義務（予見義務）

(2)被害があるとされるものを回避するための方法

調查項目：代替策の検討，リスク分析

考 慮 点：注意義務の高度化 結果の回避
産業界や個人の自主的な努力や地域に応じた規制が必 要となる。

環境ホルモン化学物質の疑いが高い有機錫化合物は, 2)（Well-Posed Controversy）の域に達しているが, 有機錫化合物がもつ別の有害性によって「化学物質の 審査及び製造等の規制に関する法律」で第 1 種特定化 学物質に指定 (1989 年) され, 既に製造, 使用, 輸入 が禁止されている。

一般公衆の間では，3）(Probable）に達しているも のが多く存在しており, 科学的根拠が明確にならない 


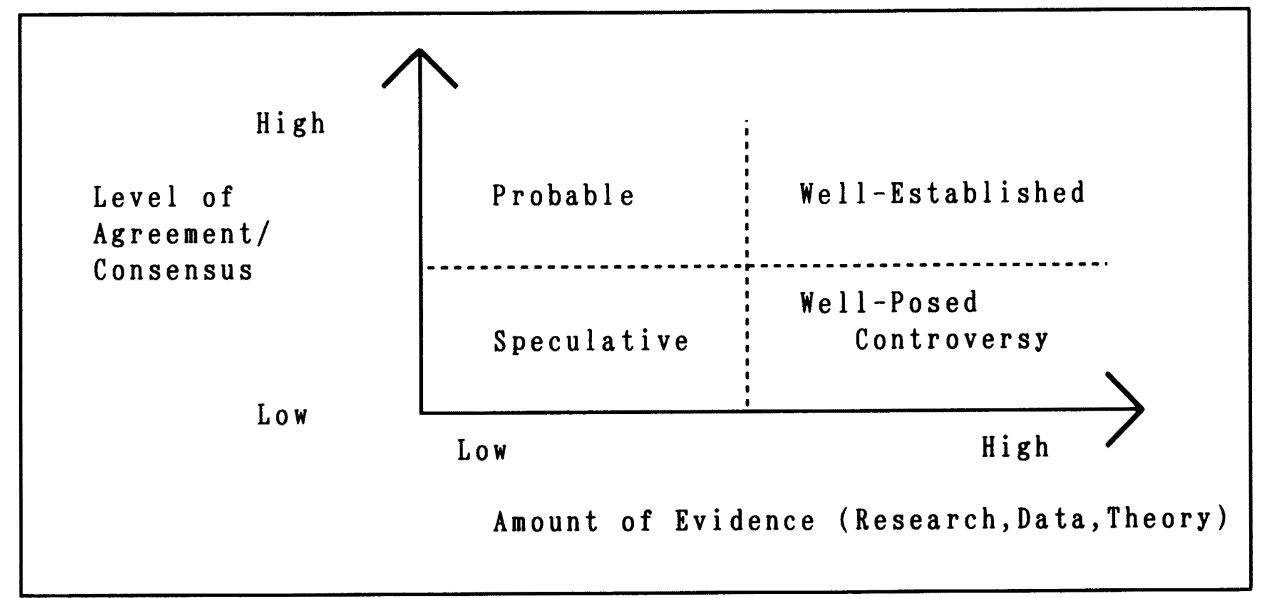

出典:IPCC Chair Elect / TSU WGII Integrated Assessment Modeling Workshop 10 March 1997 資料より

図 3 影響の証明と同意水準

まま，社会的インパクトのみが大きくなりつつある。 産業界及び関連研究者の間では, 図 3 の $\mathrm{y}$ 軸の低い部 分での争いが行われており, その証明度もまだ1) (Speculative) の座標域内での争いが中心と考えられ る。

環境ホルモン污染に起因している加害者は，これま での社会システムで慣習的に実施されてきた行為を 行った者であり, 事前の予測は不可能であったと言え る。但し，環境ホルモンの人への影響は不明のままで あるので過失の存在は確定していない。しかし生態系 及び人体への影響の研究結果や見解についての, 調査 義務は生じていると思われる。新潟水俣病地裁判決の ような最高の分析技術をもっての調査義務の必要性に ついては条件設定が困難と思われるが，可能な限りの 注意義務を履行することが不可欠であろう。

当該污染は, 加害行為の時期にずれが生じているこ とと, 起因度合に大きな差異を生じていることから, 定量的な検討や関連業界間や一般公衆とのリスクコ ミュニケーション等の調整は極めて困難と思われるが, 客観的なコンセンサスが得られる解決策への議論が必 要である。

\section{4. 内分泌翼乱化学物質に関する産業界の 取り組み}

内分泌攪乱化学物質と民間企業の関わりに関しては, 社会に与える影響の重大性等から考え, '正確かつ慎重 に検討する必要がある。

現在, 有害性や緊急性, また因果関係の確実性等々 の高低を詳細に検討することなく，「疑わしきは罰す」
との考え方のもと本件を論ずる論調も一部にはあるが, 社会活動全般における企業活動の重要性を鑑みれば, その検討に際しては, より精緻に，

・社会に与える影響はどうか (有害性の強弱, 緊急 性の度合, 因果関係の確実性等)

・ 今何が問題となっているか

・ 今後何が問題となりうるか

・代替手段としてどのようなものが考えられるか

・リスク評価は如何になされるか

等の様々な観点からの分析が必要と考えられる。

本件に対する各業界の反応を知るため，幅広い業種 に渡り調査を実施した。全体的には各社とも, 強い関 心は有しつつも，及ぼす影響や生ずるリスクが現状で はまだ不透明であること等から，自社の関わり方や対 策の講じ方等について，また明確な方針が定まってい ない場合が多いように感じられる。また, ニーズとし ては, 他社・他業態での対策内容や社内体制, 代替手 段の有無等に関する情報の収集等がある。以下に幾つ かを列記する。

(1)製造業全般

業界別で見ればやはり，本件に最も関連の深い製造 業で関心が高い。但し，その中でも，直接化学物質 を製造する企業と，これを原料として他の製品を製 造する企業, また, 工場での製造過程で何らかの化 学物質を使用する企業等々の間で, 関心の度合, 对 策を講じる度合については温度差がある。

(2)商業, 流通業

取扱い商品が実際に社会問題化した場合, 社会的な 企業イメージダウンや手間のかかる商品回収が発生 
する等, 受ける影響自体は大きいが, 但し, 直接当 該商品を製造しているわけではないことから, 対応 については慎重に検討中である。

(3)保 険 業

保険業界では，「環境ホルモン保険」に対する社会的 ニーズの高まりや, 自社差別化の可能性等も認識し ているが, 現状での因果関係の不透明性, また将来 的に発生するリスクの定量化の困難性等々から, 商 品化については課題も多いとの判断がある。

\section{5. 企業と一般公衆の見解}

本研究で行った企業の対応策, 及び一般会衆の意見 についてのヒアリング結果を次に示す。

\section{1 企業の対応}

（1）個別企業が独自に有害性を研究することについ $\tau$

次の 2 点の理由により消極的姿勢が見られた。

(1)個別企業で製品の有害性を研究するには, 経済的 に困難である。

(2)個別企業で安全性を確認しても，社会的信用が受 けられにくい（自社に都合の良いデー夕を作成し ていると思われる可能性がある)。

(2) 公的機関による有害性の研究について 次のような慎重な対応が必要である。

(1)注意が必要な対象物質の抽出, 有害性の確認等に ついては様々な角度から十分に調査研究した後で 公表する。

(3) 有害性が確定された後の対処について

(1)内分泌攪乱化学物質を含む材料の代替材料や代替 技術の開発は早急には困難である。

\section{2 一般公衆の意見}

(1) 生活への影響（一般公衆の㦟念）

一般市民の本物質のリスクへの慜念は，大きく分け て次の三つに分けられる。

(1)廃棄物処理場の燃焼処理による大気污染

(2)工場, 研究所等からの排気, 排水

(3)食品, 生活用品の捸取, 接触による人体への影響

(2) 誤 解

環境ホルモン物質の污染について誤解を生じていた ところを次に示す。

(1)焼却の際に有害物質が発生し問題となる材料を, 通常の使用時においても同様の危険感を抱いてい る。

(2)可塑剤の有害性をべースの重合物（プラスチック ス）そのものに対して問題としている。

(3)生活の周りに非常に多くの污染問題が散在してお
ク，注目すべき点が不明確となっている（問題の

性質自体の分類が必要となっている。)。

物質名と材料名の区別は難しく, 材料の中には主要 な物質名が材料名になったものもある。一般市民の中 には, 混乱を招いている者も少なくない。また,「環境 によい」,「環境に優しい」,「環境に悪い」というあい まいなことばと，「人体に有害である」という事実とを 分けて考える必要がある。

\section{3 企業の環境活動の注目点}

企業へのヒアリング調査に基づいて現在環境対策と して注目している項目を表 4 に示す。環境ホルモンに 関しては，特に製造物責任について関心が高かった。 また，環境活動の中でも環境ホルモンへの注意は大き く捉えられており, 経営姿勢の面からも取り組むとし ている企業もあった。

\section{4 環境ホルモン物質の代替策の例}

環境ホルモンの疑いがある有害物質の既に取られた 代替策を次に示す。

（1）有機錫化合物塗料の代替策

有機錫化合物塗料の代替策として現在次のものがあ る。

(1)銅 系塗 料

・弱い毒性により，生物を寄せ付けない。

・銅は, 一般市民にあまり危険視されていないので (一般に存在している材料：抗菌性)なので, 比較 的批判無く使用できる。

・シリコン塗料に比べ值段が安く, 銅塗料の使用は 増えてきている。

(2)シリコン系塗料

・シリコンの表面特性（物理的に付着しにくい：滑 りやすくする：撥水性）により，貝等がつきにく い。

表 4 企業の環境活動の注目項目

(1) ISO 14001 環境管理システムの構築

(2)レスポンシブルケア (化学工業会)

(3)製造物責任

<問題点>不十分なリスクコミュニケーション

$\rightarrow$ 正確なりスク評価の必要性

被害と原因の科学的因果関係が不明確

樹脂をはじめ極めて多くの物質が対象

(4)PRTR 制度 ; 環境レポート

(5)廃棄物処理・リサイクル

施設・設備の延命化：情報が不足

(6)環境会計：経営姿勢の評価(投資, 融資, 業務発注) 
・現在，かなり性能の良いものがあるが，值段が高 いことがネックである。(コストは, 錫塗料に比べ 数倍高い)。

(3)電解塩素

塩素処理（クロリネーション）は，1912 年にドイッ で開発され，現在，米国でも使用されている。当初は， 液体塩素を気化させ水に吸収する方法がとられ, 水道 水の滅菌に使用された。発電所では, 海水を直接電気 分解し, 塩素を発生させる方法をとる場合がある。

(4)電撃処理

水に電気を通して魚類に電撃を与え, 感電麻痺また は致死させる方法で, 付着生物は小さいためあまり有 効ではない（海生生物の神経と反比例する電圧が必 要)。

(5)電 導 塗 膜

生物付着防止のメカニズムは基本的には, 「電解塩 素」と同様である。電極を塗料にしたもので, 壁面に 全面 (均等) に効果が期待できる。

塗装内の導電体は, 塗料内に入れた粉状カーボンを 使用する。

(6)その他

・オゾンの注入

・紫外線照射

・淡水 (真水) 注入生物の浸透圧の急激な变化によ るへい死。
・復水器冷却管等のボール洗浄/ブラシ

・機械ブラシ / 水流利用

貝が小さいうちなら効果があるが，大きくなると 取れない。

・温水処理 (熱処理)

(2) ポリ塩化ビニルの代替策

ポリ塩化ビニル (PVC) は, 廃棄物の燃焼処理の際 に発生するダイオキシンが問題となった。高温高圧の 燃焼処理によりダイオキシンの発生は，かなり抑制で きるが, 塩化水素は発生する。最近では, 添加物の DOP (デオオクチルフタレート)が環境ホルモン物質として 注目されている(表5)。

(3) 近年注目されている PCB 処理技術

近年 $\mathrm{PCB}$ 処理技術として注目されているものを表 6 に挙げる。

\section{5 環境ホルモン污染に対する企業の対処案}

(1) 社 内

社内での環境管理活動として次の項目が挙げられる。

(1) MSDS 等有害性情報の整備

(2)社員に対して作業の安全性の説明

(3)労働者のモニター（作業環境測定, 健康診断)

(2) 社外

社外に対する企業環境パフォーマンスとして実施す べき対応を次に挙げる。

(1)製造物責任（4 条：引き渡し時の科学・技術の知

表 5 ポリ塩化ビニルの代替

\begin{tabular}{c|c|c|l}
\hline & リサイクル & 廃棄物再利用 & \multicolumn{1}{c}{ バージン品単価 } \\
\hline \multirow{2}{*}{$(1) \mathrm{PVC}$} & 再成形可能 & (燃料) & $\begin{array}{l}200 \text { 円 } / \mathrm{kg} \\
\text { リサイクルの場合 } 1.5 \text { 倍となる。 }\end{array}$ \\
\hline \multirow{2}{*}{$(2) \mathrm{PE}$} & 再成形可能 & 燃料 & 150 円 $/ \mathrm{kg}$ \\
\hline 難燃性 PE & & 燃料 & $400 \sim 700$ 円 $/ \mathrm{kg}$ \\
\hline \multirow{2}{*}{ (3)架橋 PE } & 再成形不可 & 燃料 & 250 円 $/ \mathrm{kg}$ 微粉末 \\
\cline { 2 - 4 } & \multicolumn{2}{|c|}{ 廃品回収業者で再成形しているところもある。 } \\
\hline
\end{tabular}

表 6 近年注目されている $\mathrm{PCB}$ 処理技術

（1）アルカリ触媒分解法（BCD 法）

(2) 化学抽出分解法 (DMI/NaOH 法)

(3) t-BuOK 法 (カリウム・ターシャリー・ブトオキサイド法)

(4) 触媒水素化脱塩素化法 ( $+\mathrm{t}-\mathrm{BuOK}$ 法)

（5）超臨界水酸化法

* 現在, 廃棄物処理法では高温焼却処理 $\left(1,100^{\circ} \mathrm{C}\right.$ 以上) が唯一廃 $\mathrm{PCB}$ の処理法として位置づけられている。 
見)

(2)製品設計の事前検討

(3)製品の拡散経路の予測 (販売, リサイクル，廃棄)

(4)製品のマーケティング

リスクに対する世論（技術的背景と異なる場合が ある)

環境ビジネス（新規分野の開拓）

(5)企業環境パフォーマンスの評価（経営姿勢）

\section{6. 今後の取組について}

環境の概念自体，個人，主体によって様々に異なる。 まずは，環境概念についての一定のコンセンサスづく りが必要であろう。

環境ホルモン物質は, 非常に多くの種類があり, 生 体で特異な複雑な機序を有することから, 社会的にリ スクに対する大きなインパクトを与えつつある。その 解決には, 学術, 産業活動, 行政で, なわばり意識等 既成概念を取り払う必要がある。学術面では, 自然科 学, 社会科学, 人文科学間で様々な枠を取り払って議 論することが不可欠である。産業界では, 業種にとら われずに横断的な取組が望まれる。ましてや縦割り行
政など全く無意味なことであり，また特定の行政機関 のみがイニシアティブをもっても非合理的な対応とな るだろう。

環境ホルモン問題は，有害物質問題の中でも極めて 広い範囲の人間活動が対象となっているため, 個人, 各機関が協力しあった合理的な対応が期待される。

謝 辞

本研究を実施するに当たって小池明子さん（第一勧 銀総合研究所研究開発部）に，多大なるご支援を承り， ここに改めて感謝する次第である。

\section{参考文献}

1) 勝田悟 : 污染物質排出移動登録 (PRTR) 制度導 入による環境污染リスクの低下（企業法学 1998 Vol. 7, 商事法務研究会) 214 頁 231 頁

2）勝田悟：環境法の補完的機能をもつ有害物質対策 の研究 (医療廃萧物研究 Vol.11 No 1, 医療廃棄 物研究会, 1998) 23 頁 230 頁

3）勝田悟：化学物質セーフティデータシート（未来 工学研究所, 1992), 292 頁 1010 頁

4) 勝田悟: 有害物質の国際的な排出規制 (月刊薬事, Vol. 38, No 9(1996 105 頁 114 頁)) 